\title{
A CARTA DAS MULHERES GREVISTAS DE 1917
}

Soldados! Não deveis perseguir os nossos irmãos de miséria. Vós também sois da grande massa popular e, se hoje vestis a farda, voltareis a ser amanhã os camponeses que cultivam a terra ou os operários explorados das fábricas e officinas.

A fome reina nos nossos lares e os nossos filhos nos pedem pão. Os perniciosos patrões contam, para sufocar nossas reclamações, com as armas de que vos armaram, oh! Soldados.

Essas armas eles vol-as deram para garantir o seu direito de esfomear um povo.

Mas, soldados, não façaes o jogo dos grandes industriais que não têm pátria.

Lembrai-vos que o soldado do Brazil sempre se oppoz à tyrannia e ao assassinato das liberdades.

O soldado brasileiro recusou-se no Rio, em 81, a atirar sobre o povo quando protestava contra o imposto do vintém e, até o dia 13 de maio de 1888 recusou-se a ir contra os escravos que se rebellavam, fugindo ao cativeiro!

Que belo exemplo imitar!

Não vos presteis, soldado, á servir de instrumento de oppressão dos Matarazzo, Crespi, Gambu, Hoffmann, etc, os capitalistas que levam a fome ao lar dos pobres e gastam milhões mal adquiridos e que esbanjam com as cocottes.

Soldados! 
Cumpri o vosso dever de homens! Os grevistas são vossos irmãos na miséria e no sofrimento; os grevistas morrem de fome, ao passo que os patrões morrem de indigestão!

Soldados! Recusavos ao papel de carrascos!

São Paulo, junho de 1917.

Um grupo de mulheres grevistas 